\title{
IMPLEMENTATION OF THE CORPORATE SOCIAL RESPONSIBILITY PROGRAM: SHOPEE FOR THE BAMBOO COMMUNITY OF PRINGGODANI
}

\author{
Dessy Isfianadewi'), Tezza Adriansyah Anwar ${ }^{2)}$ \\ ${ }^{1)}$ Departement of Management Universitas Islam Indonesia, Yogyakarta \\ ${ }^{2}$ Business and Management Faculty, Universitas Widyatama, Bandung \\ Corresponding author: dessy.isfianadewi@uii.ac.id
}

\begin{abstract}
This study aims to determine the extent of the benefits of implementing CSR programs provided by companies to the public. Specifically, this research was carried out on the implementation of CSR programs carried out by Shopee, Shopee for the Country, for the community, in this case, the Pringgodani community as the recipient of assistance. The Pringgodani community itself is located in the village of Muntuk, Yogyakarta. This village is widely known for bamboo crafts made by craftsmen in the village. With the assistance provided by Shopee, how the Muntuk village community who are members of the Pringgandani community are more developed discussed in this study. This study will use a qualitative approach using the case study method. This study will use three methods of data collection, namely: interview method, observation, and documentation to maintain data validity and reliability. The results of this study note that CSR programs carried out by Shopee, Shopee for the Country to the Pringgodani Community include: UMKM (Community) education and training assistance in workshop building, capital assistance in the form of purchasing production machinery, assistance with product promotion and marketing partners online. The success of the Shopee CSR program to improve and develop the Community's potential has provided positive results and impacts even though it has not been fully optimized. This is because there are still some obstacles in addition to the existence of several supporting factors. It can be concluded that the current needs of the Community are the existence of education and ongoing assistance to craftsmen in producing quality products and running businesses that are ready to compete. Suggestions, CSR programs should be delivered directly to the recipient community without intermediaries, so that the program implementation can be carried out directly by the community.
\end{abstract}

Keywords: Corporate Social Responsibility, Pringgodani Bamboo Comunity, Shopee Untuk Negeri

\section{Introduction}

Over the past few decades, many companies have invested considerable financial resources to implement corporate social responsibility (CSR) strategies, namely developing processes to integrate social, environmental, ethical and human rights issues into business operations and core strategies of working together with stakeholders (European Commission, 2011). This CSR is a form of corporate responsibility to the surrounding environment. So, it is expected that "a company in carrying out its business is not only based on a single bottom line, that is, corporate value or economic (profit) only but also on the triple bottom line, which is in addition to economy (profit), social aspects (people) and environment (planet) "as stated by Elkington in Handayati (2008). Outside there are many companies that carry out CSR activities but only to fulfill reports. Not many companies do CSR in a sustainable manner to foster community business. According to Thiel (2010), there are several key points that encourage CSR to be better, namely: (1) Enlightened self interest. Companies should create synergies and ethics, build sustainable social relationships and global economic markets, labor and people who can work together; (2) Social investment. Companies should contribute to the physical infrastructure, social capital to increase the part of their business work; (3) Transparency and trust. Companies that have a low perception rating in the community, so as to increase expectations, companies must be more open, accountable, and improve reports to the public about the environment and social aspects; (4) Increased public expectation of business. Global companies are expected to work more and contribute to the economy through taxes and employment.

This study aims to find out how the benefits of CSR provided by the company to the community. Specifically, this research was conducted to find out the benefits of CSR programs carried out by Shopee, Shopee for the Country, for the community, in this case, the Pringgodani community as the recipient of assistance. The Pringgodani community itself is located in the village of Muntuk, Yogyakarta. This village is 
widely known for bamboo crafts made by craftsmen in the village. With the assistance provided by Shopee how the Muntuk village community who are members of the Pringgandani community become more developed will be discussed in this study. The focus in this study are: (1) How the implementation of the Shopee program for the State is carried out as the form of Corporate Social Responsibility (CSR) implemented by PT. Shopee International Indonesia with the Pringgadani Community located in Muntuk Village, Yogyakarta ?; (2) What is the role of the supporting and inhibiting factors for the process of giving CSR to the Pringgodani Community ?; (3) How is the success of the Shopee CSR program to enhance and develop the potential of the Mantuk Pronggodani Community in Yogyakarta?

\section{Literature Reviews}

Forester (2009), conducted research on CSR at a golf company. This study aims to explore ideas of social impact, by qualitatively assessing the results of CSR initiatives of golf management companies in the elementary school system. Through a series of interviews with program stakeholders, analysis of secondary documents, and personal observations. The researcher was able to assess the impact on participants (number of 23 participants), make suggestions for improvements for the future, and ensure a level of strategic suitability between the program and the company's overall mission. This research shows that the company does have the ability to instill positive social impacts through CSR efforts. Using CSR as a means to create competitive advantage and positive social impacts must be one of the priorities for the owner of the company, the president, and the CEO. This competitive advantage cannot be realized unless CSR efforts are communicated to organizational stakeholders. In this study, the company owner communicated his CSR efforts to stakeholders, so that stakeholders were aware of the company's competitive advantage.

Meanwhile, Lee, Kim, \& Kim (2018), in their research, argued that although interest in research increased in the field of gaming company and corporate social responsibility (CSR), empirical studies of the impact of CSR company gaming companies on society were limited. Thus, the purpose of this study is to examine the impact of CSR gaming company on the quality of life of the community, perceived benefits, and support for the development of the company based on stakeholder theory and social exchange theory. The study also investigates the role of mediation in people's quality of life and perceived benefits. A survey of 459 people in the gaming community. The study found that the company's gaming CSR measured by four dimensions (economic, legal, ethical, and philanthropic) had a significant positive effect on people's quality of life. CSR also affects community support directly and indirectly.

Yusrilsya and Mahalli (2013) conducted a study that aimed to determine the role of PT.Arun CSR program in development in 12 villages in Muara Batu sub-district, North Aceh district. The CSR program includes community participation, SME capital assistance, assistance with product promotion partners, assistance from partners in building the environment and SME education and training assistance. Based on the results of the analysis, it was concluded that the PT.Arun NGL CSR program included community participation, SME capital assistance, assistance with product promotion partners, assistance to partners in building the environment and SME education and training assistance, significantly influencing the development of 12 village SMEs in Muara Batu District, Aceh Regency North.

Corporate in conducting business is always in touch with the community, both the surrounding community and the wider community, both the community in the general sense and the business community, including Micro, Small and Medium Enterprises (MSMEs). In the concept of Corporate Social Responsibility (CSR) the community (including MSMEs) are stakeholders of the company. MSMEs as stakeholders of large-scale companies still need to be empowered. In Suparnyo \& Wiwit's research, (2013) a solution or answer was sought regarding the implementation of CSR for large-scale cigarette companies in empowering MSMEs, constraints to the implementation of MSME empowerment through CSR programs, and appropriate and equitable MSME empowerment models through CSR programs. This study uses an empirical juridical approach, the data used are primary and secondary data. The implementation of CSR programs for largescale cigarette companies in empowering MSMEs has not been done much. The implementation of CSR programs is still limited to the empowerment of surrounding communities in the social and environmental fields. Constraints to implementing CSR programs in empowering MSMEs consist of internal and external constraints. The right model for empowering MSMEs for large-scale cigarette companies through CSR programs is through partnership programs, namely by providing capital assistance with low interest and given directly by companies without government or non-governmental organizations (NGOs).

In its development, MSMEs still have several obstacles. To overcome this, partnerships are used as a strategy, namely through the Partnership Program that is required for every BUMN in Indonesia as a form of 
Corporate Social Responsibility (CSR). Kusumadewi, Imam \& Wina, (2013) conducted a study that aimed to describe and analyze the implementation of partnerships between PT. Malang TELKOM Kandatel with apple processing MSMEs in Batu City as a form of Corporate Social Responsibility (CSR). The focus of this research is (1) The implementation of business partnerships carried out as a form of Corporate Social Responsibility (CSR) PT. TELKOM with apple-processed MSMEs in Batu City and (2) Supporting and inhibiting factors for implementing business partnerships. The results of this study indicate that Corporate Social Responsibility (CSR) of PT. TELKOM Kandatel Malang through the Partnership Program according to its implementation category is included in the Green Group by using a mutualistic partnership model and implementing a plasma core partnership pattern. This Partnership Program is in accordance with the Mutualism Partnership model with a plasma core partnership pattern. This partnership has been carried out optimally where the coaches have carried out their obligations to develop well so that MSMEs as their fostered partners get many benefits. But with this many benefits, it can also lead to dependence on MSMEs to continue to become partners of PT. TELKOM Kandatel Malang. To overcome this, the maximum time limit for an MSME is to become a fostered partner in the implementation of the Business Partnership Program. This maximum limit is also in addition to empowering MSMEs to provide opportunities for other MSMEs to become fostered partners of PT. TELKOM Kandatel Malang.

Condosta (2012), conducted research to understand how banks in Italy support the local economy in the face of the current financial crisis through corporate social responsibility (CSR) strategies. Research shows that banks work with a CSR approach, not only with a compliance approach but also try to support the local economy in which the bank operates. In this study, examples of how banks can integrate social needs in their daily business, improve the context and thereby enhance the reputation of the bank. This study illustrates that the financial crisis offers banks the possibility to rethink their social role and move from a compliance approach to a more strategic CSR approach.

Ragodoo (2009), states that the main purpose of his research is to analyze the contributions made by business organizations in fighting poverty in Mauritius. While on the one hand, the business is growing, but in parallel, poverty rates are increasing throughout the world. This paradoxical situation is not handled effectively by the government, because it is more interested in attracting foreign direct investment (FDI). Whereas civil society organizations lack the resources to do so. Most of the businesses surveyed already have procedures relating to the allocation of corporate social responsibility (CSR) funds. Companies are willing to help in creating a better society, whether through financial or non-financial means and indeed have the resources to do so. But only 11 percent of CSR funds are devoted to fighting poverty. This research contributes to the rare literature on CSR in Africa. Mauritian contributes to the fight against poverty through CSR. This provides an evaluation of what is being done and proposes ways through which business contributions can be increased to help more people in need.

Following the scarcity of studies in developing countries, especially Africa, regarding corporate social responsibility (CSR) and sustainable community development, Adewuyi and Olowookere (2010) through their research intend to examine the case of a large cement company, WAPCO plc, and the surrounding community. Analysis of 15 CSR factors shows that WAPCO has carried out community assistance and development for sustainable development in the local community. However, WAPCO's position seems unclear in the area of reporting social and environmental aspects, and a code of ethics regarding bribery and corruption. Some areas such as health do not appear to be given priority in the WAPCO CSR budget. WAPCO companies and other polluting companies must devote more resources to CSR activities. In addition, there is a need to design clear policies/strategies and enforcement mechanisms in the field of social and environmental reporting, and a code of ethics regarding bribery and corruption. The health sector needs to be given priority in the expenditure and regulations of the company's CSR.

Through an article written by Indira (2018), at the Cisco India Summit 2018, the company highlighted various initiatives and programs to have a positive impact on 50 million recipients of assistance in India by 2025. This goal is in line with Cisco's global vision that affects 1 billion people worldwide in 2025 through digital solutions. As part of its Corporate and Social Responsibility efforts, Cisco highlighted the importance of the role of information and communication technology (ICT) and public-private partnerships to accelerate the resolution of global problems and have a positive impact on individuals, society and the earth. Cisco also uses its strength in connecting people to the internet network and works to create strong ecosystems including governments and community organizations in India to influence real changes in the fields of education, economic empowerment, and environmental sustainability. Cisco is preparing IoT makerspaces "Cisco 
thingQbator" networks or innovation laboratories in five academic institutions in India with the aim of developing digital skills and empowering entrepreneurship among the student community. Cisco collaborated with the NASSCOM Foundation for program implementation. Cisco also supports N / Core, an incubator for social sector startups, to launch $\mathrm{N} /$ Core tech as an exclusive path that focuses on early-stage non-profit incubation that utilizes digital technology to have a positive impact on society and resolve some of the most pressing social challenges in India. N / Core technology will focus on incubating companies that develop solutions in the fields of education, and economic empowerment. Cisco will support up to 20 organizations during the first year in two groups. Each selected startup will receive an innovation grant worth INR 10 Lakh. In addition, startups will have access to a number of mentors and technology experts from Cisco along with $\mathrm{N} /$ Core partners.

Singh (2014) conducted a study to develop theoretical and empirical relationships between corporate social responsibility (CSR) initiatives from business organizations and the bottom of the pyramid (BOP) market development efforts. Researchers used in-depth qualitative interviews from 21 heads of CSR of business organizations and CSR partner organizations in India (emerging markets) to explore, develop, and explain reasonable theoretical relationships between organizational CSR initiatives and their market development efforts in the BOP using the theory of market separation. This study shows that market development in BOP is improved using the CSR route in several ways. This study has several theoretical and managerial implications that link the organization's market development efforts in BOP with its CSR initiatives.

Thiel (2010) who conducted research in Singapore found 6 (six) keys that must be studied to produce innovative CSR models. The six keys are:

1. Corporate social responsibility starts from an individual. The results of the study found that many factors make the implementation of CSR effective, but the most decisive factor is individuals who wish to improve the country, company, and society in a better direction. It is expected that global leaders/companies link CSR with individual workers, leadership and organizational value as the core of the global business strategy.

2. The implementation of effective CSR must be collective and collaborative. The whole practice of global CSR wants the leaders of global companies and their employees to be simultaneously knowledgeable about culture simultaneously. Thus, complex global issues can be solved successfully when global leaders and individual workers collaborate.

3. Corporate social responsibility can increase Return on Investment (ROI) when economic, social and environmental performance is the same. If good economic performance will contribute to the social sector. Therefore, economic performance, it is important to improve competitive advantage and quality of life because of the economy, competitive advantage, and community and natural resources are interrelated. Thus, ROI increases when global organizations are integrated with economic, social and environmental performance.

4. Human Research Development can spur cross-cultural. CSR in a global organization. Human resources are strategic capital that is very important in planning economic strategies. Professional human resources will help inter-cultural competencies and managers to work more effectively in managing workers with diverse cultures. Therefore HRD plays a role in increasing the competitiveness of global corporate organizations through the implementation of good CSR.

5. Corporate social responsibility wants individual ethics, law enforcement, oversight mechanisms, structures, systems, and business practices.

6. Corporate social responsibility wants global leaders to integrate cross-cultural CSR in organizational culture. Cultural negotiation styles, which are based on strategic negotiations and tactics by managers from various managers who are different cultures are sensitive aspects of management. Therefore, effective CSR in global organizations is how global leaders integrate across cultures in organizational culture.

Other research aims to conceptualize how businesses and communities together develop efforts to maximize welfare. This study uses a conceptual framework that links eight components of well-being (economic, environmental, social, cultural, psychological, spiritual, material and physical), with stages of mutual awareness and evolution between business and society. The stages of consciousness: traditionalist, modernist, post-modernist and integral, moderate the pace and direction by which business and society evolve into the largest welfare of the largest in eight components of well-being (Newey, 2018) 
Still related to CSR, research provides a different historical perspective on the evolution of CSR as a conceptual paradigm by reviewing the most relevant factors that have shaped understanding and definitions, such as academic contributions, international policies, and significant social and political events. To do so, the method used is a comprehensive literature review that explores the most relevant academic contributions and public events that have influenced the process of evolution of CSR and how to do it. The findings show that an understanding of corporate responsibility has evolved from a limited generation of earnings to include a broader set of responsibilities to the latest belief that the company's main responsibility is the generation of shared value. This finding also shows that when social expectations of company behavior change, so do the concept of Corporate Social Responsibility. The findings indicate that CSR continues to be relevant in the academic literature and can be expected to remain part of the business vocabulary at least in the short term and as a result, it presents a reasonable future for CSR that considers its historical evolution. (Agudelo, Jóhannsdóttir, \& Davídsdóttir, 2019)

Research that discusses the exploration of global corporate social responsibility (CSR). The purpose of this study is to theoretically explore the available CSR literature and assess empirically the implementation of CSR in India. This study offers insights into the mode of implementation of CSR in India derived from qualitative data analysis, which was obtained through in-depth interviews using a semi-structured questionnaire with functional leaders from nine Indian Companies. Observations are made in different implementation modes and professional roles in each mode. Various factors that determine the objectives of each implementation mode are identified and the reasons behind implementing various modes of CSR implementation are explored (Elembilassery \& Gurunathan, 2018)

Research on the case of pioneering experience in Mexico regarding the relationship between academics and the oil company segment that tried to assess the social impact of the activities carried out and implemented a Corporate Social Responsibility scheme under federal regulations. To achieve this, the work team of the Universidad Autónoma Metropolitana has developed a methodology that uses quantitative and qualitative data. The main results of this case study show that it is necessary to develop an appropriate approach and assessment methodology for implementing Corporate Social Responsibility measures in each region to stimulate local development. In addition, there are two important conditions for truly achieving results for local development by investing in the community in the context of CSR actions in oil production areas. The first condition is 'territorialization' of the proposal, and the second is the creation of various types of CSR actions (Garcia \& Chiang, 2018).

Dias, Rodrigues, Craig, and Neves (2018) discuss Corporate Social Responsibility (CSR) focusing primarily on large companies. Only recently have discussions about the involvement of small and medium enterprises (SMEs) in CSR emerged in research studies. This research contributed to a growing discussion about CSR in SMEs by analyzing the practice of disclosing 57 Portuguese companies of various sizes (small, medium, large). The research uses stakeholder theory to identify stakeholders prioritized by SMEs and large companies. Through thematic content analysis and disclosure index (calculated based on company type and type of stakeholder) analyzed whether business characteristics influence CSR disclosure strategies.

It was found that companies prioritize CSR activities that are directly related to maintaining business and achieving economic results. The practice of disclosing CSR by SMEs and large companies are not significantly different. However, large companies reveal more information about the environment and society. Companies that are closer to consumers reveal more information about customers, communities, and society. Actions to ensure CSR reports encourage system improvement and extend CSR disclosures (Dias, Rodrigues, \& Craig, 2018)

\section{Research Methods}

This study uses a qualitative approach using the case study method, (Yin, 2014; Creswell, 2018). This study uses three methods of data collection, namely: interviews, observation, and documentation to maintain data validity and reliability (Yin, 2014). The case used is a CSR program carried out by Shopee, Shopee for the Country, for the community, in this case, is the Pringgodani community as the recipient of assistance. The Pringgodani community itself is located in the village of Muntuk, Yogyakarta.

\section{Results And Discussion}

The role of CSR programs carried out by Shopee, Shopee For the Country to the Pringgodani Community includes: UMKM (Community) education and training assistance in workshop building, capital 
assistance in the form of purchasing production machinery, assistance with product promotion and marketing partners online

The Pringgodani Community is a community under the auspices of the Rujak Urban Center located in Jakarta. The Pringgodani community itself is in the village of Muntuk, Yogyakarta. The Pringgodani Community is a community that moves to accommodate bamboo craftsmen in the village of Muntuk. The people of Muntuk village know more about it as Bumi Pemuda Rahayu, which means a group of residents who move together to make the village Muntuk better.

Bumi Pemuda Rahayu is not only engaged in bamboo crafts but also engaged in education. Where in Muntuk village there is an educational tourism area but still has a bamboo concept. The Bumi Pemuda Rahayu area itself is not marketed too commercially because the main purpose of this community is to learn together. Growing the learning space so that villagers and tourists who come can discuss each other and learn from each other in Muntuk village.

The Pringgodani community is a community engaged in bamboo craftsmen. This community aims to unite craftsmen in the village of Muntuk and also provide education about bamboo. The advantage of the Pringgodani community from other communities is that bamboo craftsmen here are not only taught to make and sell. But it also teaches how the life cycle of bamboo lives and preserves it. So as to guarantee the rotation of bamboo that does not damage the environment.

The products offered by this community are also known to be very environmentally friendly because they do not use chemicals as bamboo preservatives. The community learns how to use sturdy bamboo without having to damage nature. Bamboo products from the Pringgodani community are famous for prices above the average. Because they have learned the techniques of carving and processing bamboo with high quality and precision.

This community has a lot of support from various parties. Among the artists and architects of the world.

The focus of this community is learning together. So that it is not too commercial among tourists. This Pringgodani community is only known in certain clusters. With the concept of learning, this community has begun to study management, where there are several divisions within the craftsmen themselves to manage finances, order, then go down to craftsmen.

1. Implementation of the Shopee Program for the Country

In this globalization era, business competition is very tight. MSMEs must be able to compete globally. MEA is indiscriminate in business competition. MSMEs as business actors are required to be able to adapt to changes that will occur continuously.

The Shopee Program for the Country is present in the Pringgodani Community to help the Pringgodani Community adapt to the global era. The CSR program is delivered in the form of 2 (two) programs, namely in the form of 3 (three) workshop activities and providing assistance in the form of purchasing production machinery. The workshop activities carried out to the Pringgodani community consisted of 3 themes, namely: branding, photography, and market place.

Workshop with the theme of branding is taught to community administrators. This shows Shopee's concern that branding is very necessary for bamboo products produced by the Prongodani Community. Branding is one of the keys to business success so that customers can remember it. Shopee invites the media to cover the community management's explanation of bamboo products produced so that they are exposed to online media.

In the session with the theme of photography, Shopee gave workshop activities in Muntuk village to all members of the Pringgodani Community. In this session, Shopee focused more on simple photo techniques that can photograph products so that they are attractive to customers. This workshop was responded positively by members of the Pringgodani community because it is new knowledge and very useful for exposing products and becoming more confident to promote their products,

In the third workshop, Shopee educated about the market place. In the current era of globalization, selling products is not only done by presenting products physically that require a place to display products (for example, in stores, malls, etc.) but can also be done through e-commerce. Through this workshop, it is hoped that it can open the horizons of the Pringgodani community to market their products online (go online) so they can penetrate markets without limits and obstacles.

After giving workshop activities, PT. Indonesia International Shopee provides assistance in purchasing machinery for the production section of the Pringgodani Community. With the help of this production 
machine, it is hoped that the Pringgodani Community is able to increase the quantity of production so as to be able to meet the demand of domestic and international markets with better quality.

2. Supporting and inhibiting factors for the process of giving CSR to the Pringgodani Community.

$\checkmark$ Supporting Factors

a. The Pringodani Community is a Community that is ready and very open in accepting input, easily formed to become more advanced and has good knowledge and skills about its products.

b. The community is always facilitated to increase knowledge by inviting the best artists.

c. Expert craftsmen in making bamboo arches (once a speaker in India and the Philippines). So that the resulting product is loaded with high aesthetic value. To maintain product quality, there are already SOPs for the production process (how to brush, precision to smooth, etc.)

d. The community has a sustainable concept for its products. The bamboo concept is sustainable by observing the continuation of bamboo's life through replanting. Do not use chemicals as preservatives. Pure bamboo is coated with the cat's eye (rubber sap to polish the product). A special place for bamboo planting and preservation is provided in Kulonprogo.

e. The quality of the bamboo products produced has good quality and is strong because it uses bamboo skin as a raw material for the product.

f. Through the introduction and awareness of the importance of branding on its products, it is hoped that the Pringgodani Community will begin to introduce and position its products to the community so that their products are known for quality and environmentally friendly products.

g. As a business engaged in the handy craft. It is time for the Pringgodani community to learn good photography techniques to support their business so that they can be known and accepted by the market so that they are expected to increase sales and income.

h. Education about online shops can add insight and make members of the Pringgodani community aware that they have now entered the era of global competition. By studying the market place, the Pringgodani community became aware of the importance of product introduction through e-commerce. So that it is expected that the Pringidani Community products are better known and easily accessed by domestic and international consumers.

\section{$\square$ Obstacles Factors}

The purpose of PT. Indonesia International Shopee through CSR programs is providing education and training assistance, capital assistance and product promotion partners and suppliers through online. The hope is that the Pringgodani Community can immediately implement all the assistance provided. But now the Pringgodani community is still in trouble and faces several obstacles:

a. Craftsmen have not focused on their business activities but are still constrained by family affairs

b. Craftsmen carry out their production activities based solely on continuous orders

c. Craftsmen have not carried out management activities. Management is still being carried out by the Rujak Urban Center in Jakarta. So that craftsmen do not know and feel the development of their business.

d. Craftsmen do not know about Shopee CSR programs so that the program implementation has not been maximized

e. It is not easy for the community to find human resources who are able to focus on implementing management in the fields of marketing, finance and production

f. The unavailability of human resources who understand product design knowledge and manage Instagram (social media)

g. Limited marketing reach, limited to certain consumers who already know and have networks (Indonesia, Japan and Australia)

h. Product prices are relatively expensive, because they maintain different quality and production techniques.

i. The website has not been rehabilitated and updated.

3. The success of the Shopee CSR program to enhance and develop the potential of the Pringgodani Community 
The Shopee CSR program has not been optimal in improving and developing the potential of the Pringgodani Community. This happens due to:

a. Programs are not delivered directly to the community but through intermediaries so that the community does not feel any direct assistance. Communities only carry out existing activities without involvement in the planning, implementation and evaluation of CSR programs.

b. The new CSR program has touched the surface of the problem yet to the root of the problems faced by the Communities of Pringgodani so that it is not optimal to improve and develop the potential of the Pringgodani Community.

\section{Conclusion and Suggestion}

The CSR program carried out by Shopee, Shopee for the Country to the Pringgodani Community includes UMKM (Community) education and training assistance in workshop building, capital assistance in the form of purchasing production machinery, assistance with product promotion and marketing partners through online. The success of the Shopee CSR program to enhance and develop the potential of the Mantuk Pronggodani Community in Yogyakarta has provided positive results and impacts, although not yet fully optimized. The success is supported by craftsmen who have specific expertise, competitive product quality and community care for the sustainability of product raw materials and environment. But on the other hand, there can also be found some obstacles in conveying, implementing and preparing the community as recipients of assistance. These obstacles include: craftsmen have not focused on their business, relatively expensive product prices, have not used relevant technology, the unavailability of human resources who run management, and community ignorance of the existence of CSR programs.

So that it can be concluded that the current needs of the Community are the existence of education and ongoing assistance to craftsmen in producing quality products and running businesses that are ready to compete on a national and international scale.

The CSR program should be delivered directly to the recipient community without intermediaries so that the implementation of the program can be carried out directly by the community. The community understands the process, form, and purpose of the CSR program. The community can feel the benefits directly, both short and long term. It is expected that the evaluation of the successful implementation of the CSR program can be measured clearly.

\section{References}

Adewuyi, Adeolu O. dan Afolabi E. Olowookere. (2010). CSR and sustainable community development in Nigeria: WAPCO, a case from the cement industry. Social Responsibility Journal, 6 (4), 522-535.

Agudelo, M. L., Jóhannsdóttir , L., \& Davídsdóttir, B. (2019). A literature review of the history and evolution of corporate social responsibility. International Journal of Corporate Social Responsibility, 4, 1-23.

Condosta, Luca. (2012). How banks are supporting local economies facing the current financial crisis: An Italian perspective. International Journal of Bank Marketing, 30 (6), 485-502.

Creswell, J. (2018). Research Design: Qualitative, Quantitative and Mixed Methods Approach, 5th Edition. SAGE Publisher

Dias, A., Rodrigues, L. L., \& Craig, R. (2018). Corporate social responsibility disclosure in small and medium-sized entities and large companies. Social Responsibility Journal. 15, 137-154

Elembilassery, V., \& Gurunathan. (2018). Mandated CSR and mode of implementation: the Indian context. Social Responsibility Journal, 14, 701-718.

European Commission (2011). Communication from the Commission to the European Parliament, the Council, the European Economic and Social Committee and the Committe of the Regions: A renewed EU strategy 2011-14 for Corporate Social Responsibility.

Forester, Brooke E. (2009). The Social Impact Of Corporate Social Responsibility: A Case Study. Dissertation. Florida State University College Of Education.

Gandhi, Indira. (2018). Cisco highlights CSR initiative at Cisco India Summit 2018. Athena Information Solutions Pvt. Ltd

García, A., \& Chiang. (2018). Corporate social responsibility in the Mexican oil industry: Social impact assessment as a tool for local development. International Journal of Corporate Social Responsibility, 3, 3-15.

Handayati, P. (2008) Implementasi Corporate Social Responbility sebagai Upaya Mengatasi Konflik Saluran Udara Ekstra Tinggi (Sutet) (Studi Kasus pada PLN Kota Malang). Penelitian Pendidikan, 18 (1). $127-143$. 
Kusumadewi, Tutut Adi, Imam, Hanafi, dan Wima, Yudo Prasetyo. (2013). Kemitraan BUMN dengan UMKM sebagai Bentuk Corporate Social Responsbility (CSR) (Studi Kemitraan PT. Telkom Kandatel Malang dengan Umkm Olahan Apel di Kota Batu). Jurnal Administrasi Publik (JAP), 1 (5), 953-961.

Lee, Choong-Ki, Kim, Jungsun dan Kim, Jinok Susanna. (2018). Impact of a gaming company's CSR on residents' perceived benefits, quality of life, and support. Tourism Management 64, 281-290.

Newey, L. R. (2018). Well-being as a staged social responsibility process for business and society. Social Responsibility Journal, 15, 75-89

Ragodoo, Nicolas J.F. (2009). CSR as a tool to fight against poverty : the case of Mauritius. Social Responsibility Journal, 5 (1), 19-33.

Suparnyo, Anggit Wicaksono, dan Wiwit, Ariyani. (2013). Model Pemberdayaan Usaha Mikro Kecil dan Menengah (UMKM) Melalui Program Corporate Social Responsibility (CSR) pada Industri Rokok di Kudus. Jurnal Sosial Budaya 6 (2).

Singh, Ramendra, Madhupa Bakshi, dan Prashant Mishra. (2014). Corporate Social Responsibility: Linking Bottom of the Pyramid to Market Development? Journal of Business Ethics 131, 361-373.

Thiel, Monica. (2010). "Innovation in Corporate Social Responsibility from Global Business Leaders at Panasonic, Thomson Reuters and Nanyang Business School", American Journal of Economics and Business Administration 2(2):194-200.

Yin, R. K. (2014). Case Study Research: Design and Methods 5th Edition. London: Sage Publication.

Yusrilsya, Muhammad dan Kasyful Mahalli. (2013). Peranan CSR PT. Arun NGL dalam Pengembangan UKM Di Aceh Utara. Jurnal Ekonomi dan Keuangan 1 (11). 